Chacón-Monge, J.L., Azofeifa-Solano, J.C., Alvarado, J.J., \& Cortés, J. (2021). Área de Conservación Guanacaste Echinoderms, North Pacific of Costa Rica. Revista de Biología Tropical, 69(S1), 487-500. DOI 10.15517/rbt.v69iSuppl.1.46391

DOI 10.15517/rbt.v69iSuppl.1.46391

\title{
Área de Conservación Guanacaste Echinoderms, North Pacific of Costa Rica
}

\author{
José Leonardo Chacón-Monge 1,2,3* $^{\text {1. }}$ \\ Juan Carlos Azofeifa-Solano ${ }^{1}$ \\ Juan José Alvarado 1,2,3 \\ Jorge Cortés ${ }^{1,2}$
}

1. Centro de Investigación en Ciencias del Mar y Limnología, Universidad de Costa Rica, San Pedro, San José, Costa Rica; jose.chaconmonge@ucr.ac.cr (*Correspondence), juan.azofeifa@ucr.ac.cr, juan.alvarado@ucr.ac.cr, jorge.cortes@ucr.ac.cr

2. Escuela de Biología, Universidad de Costa Rica, San Pedro, San José, Costa Rica

3. Centro de Investigación en Biodiversidad y Ecología Tropical, Universidad de Costa Rica, San Pedro, San José, Costa Rica

Recibido 29-VII-2020. Corregido 20-X-2020. Aceptado 27-X-2020.

\begin{abstract}
Introduction: The study of the marine diversity of the North Pacific of Costa Rica began with isolated foreign expeditions in the 1930s and was systematically developed in the mid-1990s by the Center for Research in Marine Sciences and Limnology, Universidad de Costa Rica, as consequence there are now a total of 1479 reported species in this region. Objective: Present an update to the echinoderm richness of the Guanacaste Conservation Area. Methods: We sampled 25 localities exhaustively and estimated similarity between sites based on the family richness and environmental heterogeneity. Results: We found 61 taxa, which represent 26 $\%$ of the echinoderm reported species for the country's Pacific coast. Of these, 43 species are new records for the Guanacaste Conservation Area, and seven for Costa Rica and Central American Pacific coasts. We found three morpho-species that do not match to available descriptions of the Eastern Tropical Pacific echinoderm species. We also found the holothuroid Epitomapta tabogae, and the ophiuroid Ophioplocus hancocki, previously thought endemic to Panama and the Galapagos Islands, respectively. The proximity of the sampled sites and the redundancy of certain families may explain why we did not find important differences among localities. Conclusions: The echinoderm richness of this conservation area is at least $20 \%$ higher than previously reported, reaching similar levels to those in other high diversity sites of the Eastern Tropical Pacific.
\end{abstract}

Key words: Murciélago Islands; Santa Elena; coastal upwelling; scientific collections; taxonomy; Echinodermata.

The North Pacific region of Costa Rica is divided into two conservation areas, managed by the Ministry of Environment and Energy, Tempisque and Guanacaste. These two conservation areas cover part of the province of Puntarenas and all of Guanacaste (Alvarado, Cortés, Esquivel, \& Salas, 2012). The Área de
Conservación Guanacaste (ACG), is northernmost Costa Rica's protected area and borders Nicaragua. The ACG marine protected area comprises $430 \mathrm{~km}^{2}$ and $150 \mathrm{~km}$ of protected coastline, and it includes 732 ha of Santa Elena Bay Management Marine Area, and the Marine Sector of Guanacaste National Park, including 
the archipelago of the Murciélago Islands (Fig. 1). This region is subjected to strong seasonality, with a dry season that runs from December to April, a first rainy season from May to June, and a second from August to October. During the dry season, the influence of northeast trade winds increases, causing a seasonal tropical upwelling, that exposes shallow coastal habitats to cold, nutrient-rich, lower $\mathrm{pH}$, and high oxygenated waters (Alfaro \& Cortés, 2012; Cortés, Samper-Villarreal \& Bernecker, 2014; Lizano \& Alfaro, 2014; Cortés, 2016).

Entirely, ACG is managed as a mega park and operates as a conservation enterprise (Janzen, 2000; Janzen \& Hallwachs, 2016; Janzen \& Hallwachs, 2020). Being a world's reference in management as a conservation and restoration area, therein remains the latest relict of the uninterrupted and protected landscape that integrates the more endangered and complexes neotropical habitats (e.g., open ocean, shores, hard and softs bottoms, rhodolites, algae beds, and coral reefs, wetlands, mangroves, dry, rainy and cloud forests) (WHC, 2013; Janzen \& Hallwachs, 2016; Janzen \& Hallwachs, 2019). These spatial and biologic connection becomes a sanctuary at many natural scales (physics and organics), that engages the deep sea and surface ocean, salty, and freshwater systems, that extends from the rugose Pacific shore and dry forest, to the cloud mountains, at the Atlantic basin (SINAC, 2013; WHC, 2013; Janzen \& Hallwachs, 2016; Janzen \& Hallwachs, 2020). ACG was declared as a UNESCO World Heritage site, highlighting its geographic, socio-cultural and biological importance, in administrating and secure the preservation of the natural resources, as well as shelter the genetic diversity to perpetuity (Cortés \& Joyce, 2020; Janzen \& Hallwachs, 2020).

The management areas of the ACG marine sector include zones with different protection status and use categories, as areas for absolute protection, for public, especial, and sustainable use (SINAC, 2013). There are fishing regions for semi-industrial and artisanal fisheries (Villalobos-Rojas, Herrera-Correa, Garita-Alvarado, Clarke \& Beita-Jiménez, 2014). Many beaches, shores, reefs, and islets are available for tourism, where the main activities are surfing, beach visitation, snorkeling, scuba, and sportfishing activities. Other areas are oriented to conservation, education, and or investigation due to their remarkable attributes and importance to sustain marine diversity, productivity, and to avoid ecological

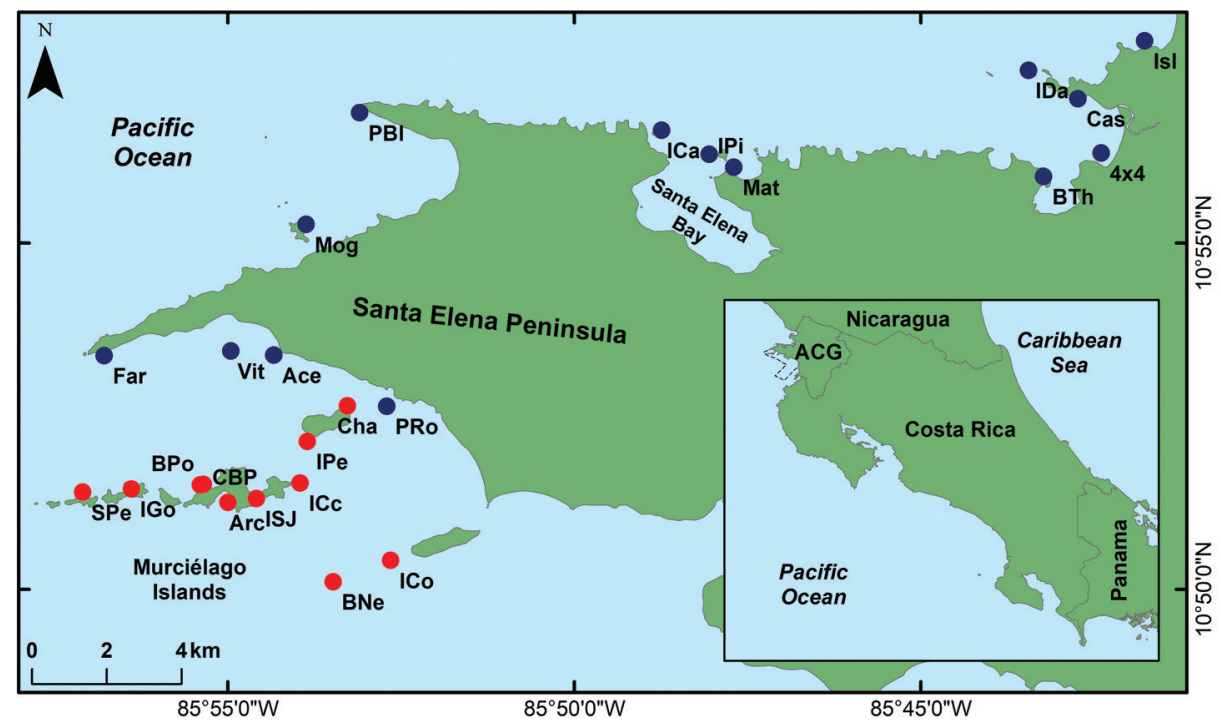

Fig. 1. Área de Conservación Guanacaste showing sampling sites. Blue dots represent peninsular sample sites, whereas the red ones represent archipelago sample sites. 
degradation (SINAC, 2013; Villalobos-Rojas et al., 2014). Despite that, there are pressures like overfishing or illegal extraction of species for aquarium and as for delicatessen (i.e., sea cucumbers) (Toral-Granda, 2008; VillalobosRojas et al., 2014). Altogether, these conditions open up opportunities for marine conservation management, and to establish the framework for accurate strategies and policies, that should be regionally implemented in order to maintain the ecosystemic services and sustainability, for wild and as well for human communities, inside and beyond of protected areas (Janzen, 2000; Janzen \& Hallwachs, 2016; Janzen \& Hallwachs, 2020).

The study of marine diversity in the ACG started in the 1930s with zoological specimens' scientific collection, during international expeditions (Cortés, 2017). However, it was not until the mid-1990's when the Center for Research in Marine Sciences and Limnology (CIMAR) of the Universidad de Costa Rica (UCR) leads the systematic exploration of marine environments and organisms of ACG (Cortés, 2017). The BioMar-ACG Project, was established to increase the knowledge of marine biodiversity in ACG. Beginning operations in 2015, with an inter-institutional partnership between CIMAR, the Museo de Zoología (MZUCR) and the Herbario de Biología (USJ) of the Universidad de Costa Rica, the Sistema Nacional de Áreas de Conservación (SINAC), and the Guanacaste Dry Forest Conservation Fund (GDFCF) (Cortés \& Joyce, 2020). According to the literature, there are 594 species of marine organisms listed for ACG, of which crustaceans, mollusks, and cnidarians, are the richest groups (Cortés, 2017). Until now, only 15 echinoderm species have been included in scientific publications for ACG (Cortés, 2017). That compilation does not include ophiuroids, although its presence is known because of direct observations at field, samplings, and specimen collections (Granja-Fernández, PinedaEnríquez, Solís-Marín \& Laguarda-Figueras, 2020). Is expected that, by redirecting sampling effort, the improvement in technology, as by the survey of deeper waters or new habitats, the echinoderm representativeness in ACG might increase (Cortés, 2017; Cortés \& Joyce, 2020).

Recording and publishing marine biodiversity of echinoderms with precise taxonomic identifications is necessary to improve research and management efforts in this Marine Protected Area, and to properly evaluate the natural response of anthropogenic impacts on these ecosystems (Worm et al., 2006; Costello, Michener, Gahegan, Zhang \& Bourne, 2013). An update of the research and study of echinoderms is presented under the BioMar-ACG Project, to complement the ACG marine biodiversity baseline compilation (Cortés, 2017). The taxonomic affinity of the collection sites was compared, according to the area that they belong (peninsula or archipelago), and the affinity between sample sites, based on the family richness and their environmental heterogeneity (area, depth, and substrate).

\section{MATERIALS AND METHODS}

Sampling: Five field trips (July 2018-August 2019) were carried out to record the richness of echinoderms in ACG, by scuba diving. Three of the expeditions visited the Murciélago Islands archipelago, and two visited the Santa Elena Peninsula and the surroundings of Cuajiniquil Bay. A total of 25 sample sites were visited (Fig. 1); 14 in the peninsular area (P: north of the Santa Elena Peninsula) and 11 in the archipelago (A: south of the Santa Elena Peninsula). We recorded geographical coordinates, depth, and substrate type at each site (Table 1). The sampling sites were selected using the criteria and the local knowledge of the parataxonomists, BioMar-ACG Project's crew, and the scientific team. Echinoderms were collected at each site between, over, and under different substrates (algae, rocks, corals, debris, and sand). At least one specimen of each morpho-species found was collected, as a taxonomic voucher of the site echinoderm richness.

Sample preparation and identification: Collected specimens were deposited in plastic containers and transferred in seawater-filled 
TABLE 1

Echinoderm sampling sites of the BioMar-ACG project, North Pacific of Costa Rica

\begin{tabular}{|c|c|c|c|c|c|}
\hline Sector & Code & Sampling site & Substrate & Lat. (N) & Long.(W) \\
\hline \multirow[t]{11}{*}{ Archipelago } & Arc & El Arco, Isla San José, Murciélago Islands & Boulders & $10^{\circ} 51^{\prime} 07^{\prime \prime}$ & $85^{\circ} 55^{\prime} 03^{\prime \prime}$ \\
\hline & $\mathrm{BNe}$ & Bajo Negro, Murciélago Islands & Boulders & $10^{\circ} 49^{\prime} 58^{\prime \prime}$ & $85^{\circ} 53^{\prime} 32^{\prime \prime}$ \\
\hline & BPo & $\begin{array}{l}\text { Bajo Pochote, Isla San José, Murciélago } \\
\text { Islands }\end{array}$ & Boulders & $10^{\circ} 51^{\prime} 22^{\prime \prime}$ & $85^{\circ} 55^{\prime} 27^{\prime \prime}$ \\
\hline & $\mathrm{CBP}$ & Close to Bajo Pochote, Murciélago Islands & $\begin{array}{l}\text { Boulders, sand and } \\
\text { gravel bottom }\end{array}$ & $10^{\circ} 51^{\prime} 22^{\prime \prime}$ & $85^{\circ} 55^{\prime} 24^{\prime \prime}$ \\
\hline & Cha & Mata de Chagüite, Santa Elena Peninsula & $\begin{array}{l}\text { Boulders, sand and } \\
\text { gravel bottom }\end{array}$ & $10^{\circ} 52^{\prime} 30^{\prime \prime}$ & $85^{\circ} 53^{\prime} 19^{\prime \prime}$ \\
\hline & $\mathrm{ICc}$ & Isla Cocinera, Murciélago Islands & Rocky reef & $10^{\circ} 51^{\prime} 24^{\prime \prime}$ & $85^{\circ} 54^{\prime} 05^{\prime \prime}$ \\
\hline & ICo & Isla Colorada, Murciélago Islands & Boulders & $10^{\circ} 50^{\prime} 16^{\prime \prime}$ & $85^{\circ} 52^{\prime} 42^{\prime \prime}$ \\
\hline & IGo & Isla Golondrina, Murciélago Islands & $\begin{array}{l}\text { Rocky and Pocillopora } \\
\text { spp. Reef }\end{array}$ & $10^{\circ} 51^{\prime} 18^{\prime \prime}$ & $85^{\circ} 56^{\prime} 26^{\prime \prime}$ \\
\hline & $\mathrm{IPe}$ & Isla Pelada, Murciélago Islands & Boulders & $10^{\circ} 52^{\prime} 00^{\prime \prime}$ & $85^{\circ} 53^{\prime} 54^{\prime \prime}$ \\
\hline & ISJ & Isla San José, Murciélago Islands & Boulders & $10^{\circ} 51^{\prime} 10^{\prime \prime}$ & $85^{\circ} 54^{\prime} 38^{\prime \prime}$ \\
\hline & $\mathrm{SPe}$ & San Pedrito, Murciélago Islands & $\begin{array}{l}\text { Boulders, sand and } \\
\text { gravel bottom }\end{array}$ & $10^{\circ} 51^{\prime} 16^{\prime \prime}$ & $85^{\circ} 57^{\prime} 09^{\prime \prime}$ \\
\hline \multirow[t]{14}{*}{ Peninsula } & $4 \times 4$ & Playa $4 \times 4$, Cuajiniquil & Boulders & $10^{\circ} 56^{\prime} 09^{\prime \prime}$ & $85^{\circ} 42^{\prime} 27^{\prime \prime}$ \\
\hline & Ace & Aceituno, Santa Elena Peninsula & $\begin{array}{l}\text { Boulders, sand and } \\
\text { gravel bottom }\end{array}$ & $10^{\circ} 53^{\prime} 14^{\prime \prime}$ & $85^{\circ} 54^{\prime} 23^{\prime \prime}$ \\
\hline & BTh & Bahía Thomas, Cuajiniquil & $\begin{array}{l}\text { Rocky and Pocillopora } \\
\text { spp. Reef }\end{array}$ & $10^{\circ} 55^{\prime} 49^{\prime \prime}$ & $85^{\circ} 43^{\prime} 16^{\prime \prime}$ \\
\hline & Cas & Las Cástula, muelle de Cuajiniquil & Rocky intertidal zone & $10^{\circ} 56^{\prime} 56^{\prime \prime}$ & $85^{\circ} 42^{\prime} 47^{\prime \prime}$ \\
\hline & Far & Farallones, Santa Elena Peninsula & $\begin{array}{l}\text { Boulders, sand and } \\
\text { gravel bottom }\end{array}$ & $10^{\circ} 53^{\prime} 14^{\prime \prime}$ & $85^{\circ} 56^{\prime} 50^{\prime \prime}$ \\
\hline & $\mathrm{ICa}$ & Isla Los Cabros, Bahía Santa Elena & Rocky reef & $10^{\circ} 56^{\prime} 29^{\prime \prime}$ & $85^{\circ} 48^{\prime} 47^{\prime \prime}$ \\
\hline & IDa & Isla David, Santa Elena Peninsula & Pocillopora spp. Reef & $10^{\circ} 57^{\prime} 21^{\prime \prime}$ & $85^{\circ} 43^{\prime} 30^{\prime \prime}$ \\
\hline & IPi & Isla Pitahaya; Santa Elena Peninsula & Boulders & $10^{\circ} 56^{\prime} 08^{\prime \prime}$ & $85^{\circ} 48^{\prime} 06^{\prime \prime}$ \\
\hline & Isl & Islita, Cuajiniquil, Santa Elena Peninsula & Rocky bottom & $10^{\circ} 57^{\prime} 47^{\prime \prime}$ & $85^{\circ} 41^{\prime} 49^{\prime \prime}$ \\
\hline & Mat & Matapalito, Santa Elena Peninsula & Pocillopora spp. Reef & $10^{\circ} 55^{\prime} 57^{\prime \prime}$ & $85^{\circ} 47^{\prime} 45^{\prime \prime}$ \\
\hline & Mog & $\begin{array}{l}\text { Mogotes, Isla Negritos, Playa Blanca, Santa } \\
\text { Elena Peninsula }\end{array}$ & Boulders and sand & $10^{\circ} 55^{\prime} 08^{\prime \prime}$ & $85^{\circ} 53^{\prime} 56^{\prime \prime}$ \\
\hline & PB1 & Punta Blanca, Santa Elena Peninsula & Sandy bottom & $10^{\circ} 56^{\prime} 44^{\prime \prime}$ & $85^{\circ} 55^{\prime} 09^{\prime \prime}$ \\
\hline & PRo & Punta Roja, Santa Elena Peninsula & $\begin{array}{l}\text { Boulders, sand and } \\
\text { gravel bottom }\end{array}$ & $10^{\circ} 52^{\prime} 30^{\prime \prime}$ & $86^{\circ} 52^{\prime} 46^{\prime \prime}$ \\
\hline & Vit & La Vita, Santa Elena Peninsula & Boulders & $10^{\circ} 53^{\prime} 18^{\prime \prime}$ & $85^{\circ} 55^{\prime} 08^{\prime \prime}$ \\
\hline
\end{tabular}

buckets to the laboratory, then classified and separated into groups by locality and taxonomic affinity. The organisms were relaxed with menthol, magnesium chloride, and alcohol solutions, in trays with filtered seawater. Each specimen was identified to the lowest possible taxonomic category, based on specialized literature for the region (Lessios, 2005; SolísMarín, Arriaga-Ochoa, Laguarda-Figueras, Frontana-Uribe \& Durán-González, 2009; Granja-Fernández et al., 2014; Solís-Marín et al., 2014; Borrero-Pérez \& Vanegas-González, 2019; Granja-Fernández, Pineda-Enríquez, Solís-Marín \& Laguarda-Figueras, 2020) and 
following the taxonomic classification proposed by WoRMS (http://www.marinespecies.org/).

The samples were tagged by site and morpho-species, with an alphanumeric code. One specimen of each morpho-species was photographed and used as a voucher for bar-coding tissue sample extraction. Samples from all vouchered specimens were sent to the Center for Biodiversity Genomics, at the University of Guelph, for DNA sequencing and barcoding (Cortés \& Joyce, 2020). That could lead us to build a barcode library (Hebert, Cywinska, Ball \& de Waard, 2003; Janzen \& Hallwachs, 2019), and will serve as a reference inventory and as the start point for many kinds of ecological, phylogeographic, systematic, genomic, and evolutive studies. The samples were cataloged and deposited in the Museo de Zoología (MZ-UCR) of the Centro de Investigación en Biodiversidad y Ecología Tropical (CIBET), Universidad de Costa Rica.

Taxonomic and spatial analysis: The lowest taxonomic hierarchy at which all samples were identified was to family level. So, the taxonomic affinity between sites was compared at this level. The family-site similitude was performed by cluster analysis. And the sites affinity was compared by a Non-metric Multidimensional Scaling Analysis (nMDS), using the geographical area (peninsula or archipelago) as groups, in addition to the family richness, depth, and substrate type as variables for the bidimensional model. The variance of groups and sites was tested with a simple one-way PERMANOVA, that compares the spread among groups, using the average values from the distances of individual observations to the centroids of their own group, in a chosen measure of dissimilarity (using Jaccard distances for richness comparison). Assuming exchangeability, where p-values are calculated by permutation, avoiding the assumption of normality, as well as being robust to the heterogeneity of unbalanced designs, and is not sensitive to differences in correlation structure among groups (Anderson, 2017). These analyzes were performed using Past 3 software.

\section{RESULTS}

A total of 497 samples were collected, distributed in 62 morpho-species, seven for Asteroidea, 13 for Ophiuroidea, 31 for Holothuroidea and 11 for Echinoidea (Table 2). Of these, three sea cucumber did not correspond to any species described for the Eastern Tropical Pacific before. We found a total 43 echinoderm species that are new records for ACG. Including seven that had not been previously reported for the Central American Pacific coasts (Isla del Coco not included) (Table 2, Table 3). With these new records, the total number of echinoderm species present on the Pacific coast of Costa Rica reaches 233, and the total number of species recorded for the country is now 306 (see Alvarado et al., 2017; Borrero-Pérez \& Vanegas-González, 2019; Cambronero-Solano, Benavides, Solís-Marín \& Alvarado, 2019; Granja-Fernández, Pineda-Enríquez, SolísMarín \& Laguarda-Figueras, 2020).

We found 27 echinoderm families, five of Asteroidea, eight of Ophiuroidea, six of Holothuroidea and eight of Echinoidea (Table

TABLE 2

Echinoderm records by Class, collected in the BioMar-ACG Project. NR-ACG = new records for the ACG; NR-CAP $=$ new records for the Central American Pacific (not including Isla del Coco)

\begin{tabular}{lccccccc}
\multicolumn{1}{c}{ Taxa } & $\begin{array}{c}\text { Number of } \\
\text { individuals }\end{array}$ & Orders & Families & Morpho-species & $\begin{array}{c}\text { Possible } \\
\text { new species }\end{array}$ & NR-ACG & NR-CAP \\
Echinodermata & 497 & 12 & 27 & 62 & 3 & 43 & 7 \\
Asteroidea & 56 & 1 & 5 & 7 & 0 & 6 & 1 \\
Ophiuroidea & 159 & 2 & 8 & 13 & 0 & 12 & 1 \\
Holothuroidea & 192 & 4 & 6 & 31 & 3 & 15 & 4 \\
Echinoidea & 90 & 5 & 8 & 11 & 0 & 10 & 1 \\
\hline
\end{tabular}


TABLE 3

Echinoderm species by site at ACG, with indication of new records. Bold = new record for the ACG; * = new record for Costa Rica (without including Isla del Coco); ** = new record for Central America; + = First record outside the archipelago of the Galápagos Islands; ++ = First record outside Panamá. Sampling sites are presented in Table 1

Taxa Sample site

Class Asteroidea (7 species)

Order Valvatida

Family Acanthasteridae

Acanthaster planci (Linnaeus, 1758)

BPo

Family Asteropseidae

Asteropsis carinifera (Lamarck, 1816) Ace; IPy; Ica

Family Mithrodiidae

Mithrodia bradleyi Verrill, 1867*

Ace; Arc; ICc; Cha; Ida

Family Oreasteridae

Nidorellia armata (Gray, 1840)

Pentaceraster cumingi (Gray, 1840)

Family Ophidiasteridae

Phataria unifascialis (Gray, 1840)

Ace; Cas; CBP; Cha. ICa; IPi, ISJ

Ace; Ica

Pharia pyramidata (Gray, 1840)

Ace; BTh; CBP; Cha; ICa; ICc; ICo; IGo; IPe; ISJ; Isl; Mog; PRo; Vit

Ace; BNe; BTh; CBP; ICa; ICc; IGo; IPe; IPi; Isl; Mog; PBl; Vit

Class Ophiuroidea (13 taxa)

Order Amphilepidida

Family Amphiuridae

IPi; ISJ; Mog

Family Ophiactidae

Ophiactis savignyi (Müller \& Troschel, 1842)

Ophiactis simplex (LeConte, 1851)

Family Ophiolepididae

Ophiolepis pacifica Lütken, 1856

Family Ophionereididae

Ophionereis annulata (Le Conte, 1851)

BNe; BPo; BTh; Cha; IGo; IPe; IPi; ISJ

$\mathrm{BNe}$; IPe; IPi; Isl

ICa; IPe; Mog; PRo; SPe

4x4; Ace; Arc; BNe; BPo; ICc; ICo; Cha; IGo; IPe; IPi; ISJ; Mog; PBl; Vit

Family Hemieuryalidae

Ophioplocus hancocki Ziesenhenne, 1935**+

Cha

Family Ophiotricidae

Ophiothela mirabilis Verrill, 1867

Ophiothrix (Ophiothrix) spiculata Le Conte, 1851

BNe; Cha; Far; ICo; IPe; ISJ; Vit

4x4; Ace; BNe; BPo; BTh; Cas; CBP; Cha; Far; ICa; ICc; IGo; IPi; Isl; Mat; Mog; PBl; SPe; Vit

Order Ophiacanthida

Family Ophiocomidae

Ophiocoma aethiops Lütken, 1859

BTh; Cas; CBP; Cha; ICc; IPe; Isl; Mat; Mog; Vit

Ophiocomella alexandri (Lyman, 1860)

4x4; Arc; BPo; BTh; Cas; Cha; CBP; Far; ICa; ICc; ICo; IGo; IPe; ISJ; Isl; Mog; PBl; Vit

Family Ophiodermatidae

Ophioderma hendleri Granja-Fernández, Pineda-Enríquez, Solís-Marín \& Arc; ICa; ICc; ICo; Far; IPe; IPi; Vit

Laguarda-Figueras, 2020

Ophioderma panamense Lütken, 1859

BNe; Cas; Cha; ICa; ICc; ICo; IPe; IPi; Isl; PRo; SPe 
TABLE 3 (Continued)

\begin{tabular}{cl} 
Taxa & \multicolumn{1}{c}{ Sample site } \\
Ophioderma teres (Lyman, 1860) & Ace; BTh; Cha; CBP; Far; ICa; ICc; ICo; IDa; \\
& IPe; IPi; ISJ; PR; SPe
\end{tabular}

Class Holothuroidea (28 taxa)

Order Apodida

Family Chiridotidae

Chiridota aponocrita Clark, 1920*

Family Synaptidae

Epitomapta tabogae Heding, 1928**++

Euapta godeffroyi (Semper, 1868)

Order Dendrochirotida

Family Cucumariidae

Cucumaria flamma Solís-Marín \& Laguarda-Figueras, 1999

Neocucumis veleronis (Deichmann, 1941)

Pseudocnus californicus (Semper, 1868)

Trachythyone peruana (Semper, 1868)*

Family Phyllophoridae

Pentamera chierchiae (Ludwig, 1886)

Thyone bidentata Deichmann, 1941**

Family Sclerodactylidae

Afrocucumis ovulum (Selenka, 1867)

Neothyone gibber (Selenka, 1867)

Order Holothuriida

Family Holothuriidae

Holothuria (Cystipus) rigida (Selenka, 1867)

Holothuria (Halodeima) inornata Semper, 1868

Holothuria (Halodeima) kefersteinii (Selenka, 1867)

Holothuria (Lessonothuria) pardalis Selenka, 1867

Holothuria (Mertensiothuria) hilla Lesson, 1830

Holothuria (Mertensiothuria) viridiaurantia Borrero-Pérez \& Vanegas-González, 2019**

Holothuria (Platyperona) difficilis Semper, 1868

Holothuria (Selenkothuria) lubrica Selenka, 1867

Holothuria (Selenkothuria) portovallartensis Caso, 1954

Holothuria (Semperothuria) languens Selenka, 1867

Holothuria (Stauropora) pluricuriosa Deichmann, 1937

Holothuria (Thymiosycia) arenicola Semper, 1868

Holothuria (Thymiosycia) impatiens (Forsskål, 1775)

Labidodemas americanum Deichmann, 1938

Labidodemas maccullochi (Deichmann, 1958)

Order Synallactida

Family Stichopodidae**

Isostichopus fuscus (Ludwig, 1875)
Ace; BNe; BPo; BTh; ICa; IGo; IPe; IPi; ISJ; Isl; Mat; Mog; PBl

IGo

IPi; ISJ; Mat

Cha; IDa; ICa; IPi; Cas; Arc

4x4; BTh; Cas; ICa; ICo; IPi; ISJ; Isl; Mat; $\mathrm{Mog} ; \mathrm{PBl}$

Cas; ICc; ICo; Far; Cha; IPi; ISJ; Isl; Mog; PBl

Ica

Ida

Cas

IPi

4x4; Ace; BPo; BTh; Cas; Cha; ICa; ICc; ICo; IDa; IPi; ISJ; Isl;

Mog; PBl; Vit

Ace; BPo; Cha; IPe; IPi

4x4; BNe; BTh; Isl; Cas; Mog

ICc; ICo; IGo; Isl; Vit

4x4; BTh; BPo; Cas; Cha; ICa; ICo; IGo; IPi; Isl; Mog; PBl; Pro

$\mathrm{BNe}$; BPo; CBP;

Ace; IPi; Mog

ICa; Ida

$4 \times 4$; Cas

4X4; Cas; Is1

IPi; Isl; PB1

BPo; CBP; Ica

Ace; BNe; BPo; Cas; IGo; IPe; ISJ; Mog;

PRo; SPe

BNe; ICc; ICo; IPe; IPi; ISJ; Isl; Mat; PBl; Vit $\mathrm{ICa} ; \mathrm{ICo}$

BNe; IGo; ISJ

CBP

Cha; ICa; IDa; IGo; IPi; ISJ 
Class Echinoidea (11 species)

Order Arbacioida

Family Arbaciidae

Arbacia stellata (Blainville, 1825; ?Gmelin, 1791)

Order Camarodonta

Family Echinometridae

Echinometra vanbrunti A. Agassiz, 1863

Family Toxopneustidae

Toxopneustes roseus (A. Agassiz, 1863)

Tripneustes depressus A. Agassiz, 1863

Order Cidaroida

Family Cidaridae

Eucidaris thouarsii (L. Agassiz \& Desor, 1846)

Order Diadematoida

Family Diadematidae

Astropyga pulvinata (Lamarck, 1816)

Diadema mexicanum A. Agassiz, 1863

Order Spatangoida

Family Prenasteridae

Agassizia scrobiculata Valenciennes, 1846

Family Brissidae

Brissus obesus Verrill, 1867

Meoma ventricosa (Lamarck, 1816)

Family Loveniidae

Lovenia cordiformis A. Agassiz, 1872* 4x4; Ace; BTh; Far; ICa; ICo; IPi; Mat

4x4; BTh; Cas; ICc

Ace; BTh; Cas; CBP; Cha; ICa; ICc; IGo; IPi; ISJ; Mog; PBl; Vit

Ace; Cas; Cha

4X4; Ace; BNe; BPo; BTh; Cas; CBP; Cha ICo; IGo; IPe; ISJ; Isl; Mat; Mog; PBl; Vit;

Ace; CBP; Cha

Ace; BTh; CBP; Cha; IPe; Mat; Mog

BPo; IPi; Vit

BPo; CBP; ICa; ICc; IPe; IPi; ISJ; Mog; SPe; Vit

Cha; CBP; Far; IGo; SPe

Ace; CBP; IGo; Pro
2). Although there are some associations between peninsular or archipelago influence sites $(\mathrm{R}=0.82)$, the taxonomic affinity at the family level was not determined by the geographical area. The clusters are heterogeneous, comparing the family richness among sites by sector (Fig. 2). The spatial distribution of the localities according to their taxonomic affinity and environmental heterogeneity, also did not reflect discrete clusters regarding the influence of the geographical area (PERMANOVA $\mathrm{p}>0.05$, Fig. 3).

Isla David and Punta Roja showed less similarity to other sample sites (Fig. 2). They present seven and six families respectively, some of them are rare for other localities (Mithrodiidae, Phyllophoridae, Stichopodidae and Cucumariidae on Isla David; Ophiolepididae and
Loveniidae at Punta Roja), in combination with widely distributed families (Ophiodermatidae, Ophidiasteridae, Holothuriidae, Sclerodactylidae) (Table 3). Another locality separated from the rest is Farallones (Fig. 2), presenting a particular family composition, some common in the peninsula sector and others in the archipelago (Ophiotrichidae, Ophiodermatidae, Ophiocomidae, Arbaciidae, and Brissidae). Localities with greater similarity by pairs in the peninsular sector (Pitahaya Island-Los Cabros Island; Punta Blanca-Mogotes) have a large number of families, some rare (Asteropseidae, Amphiuridae, Cucumariidae, Stichopodidae, Synaptidae, Prenasteridae and Oreasteridae in the first peninsular pair; Amphiuridae, Ophiolepididae, and Cucumariidae; in the second peninsular pair) in combination with other ones 


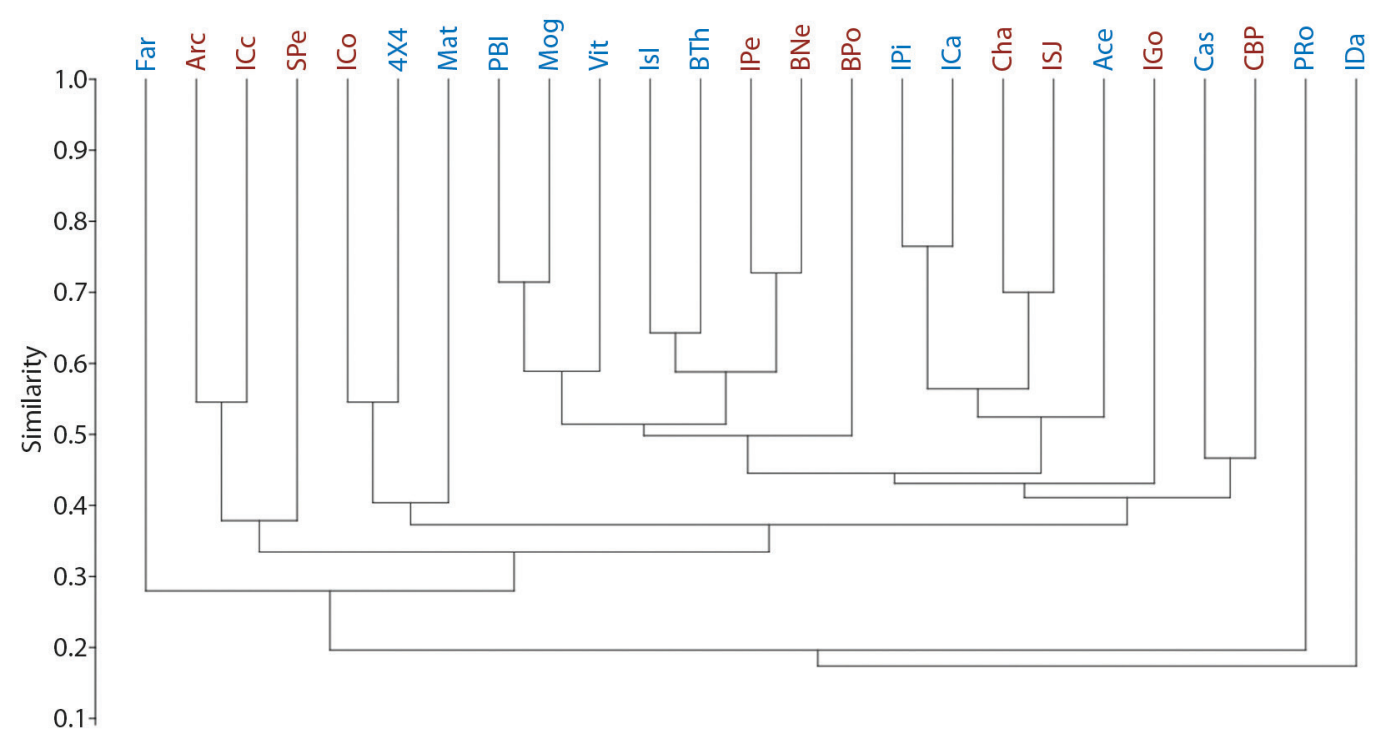

Fig. 2. Echinoderm family richness at ACG cluster. Based on Jaccard's index. $\mathrm{R}=0.82$. Blue codes represent peninsular sample sites, whereas the red ones represent archipelago sample sites.

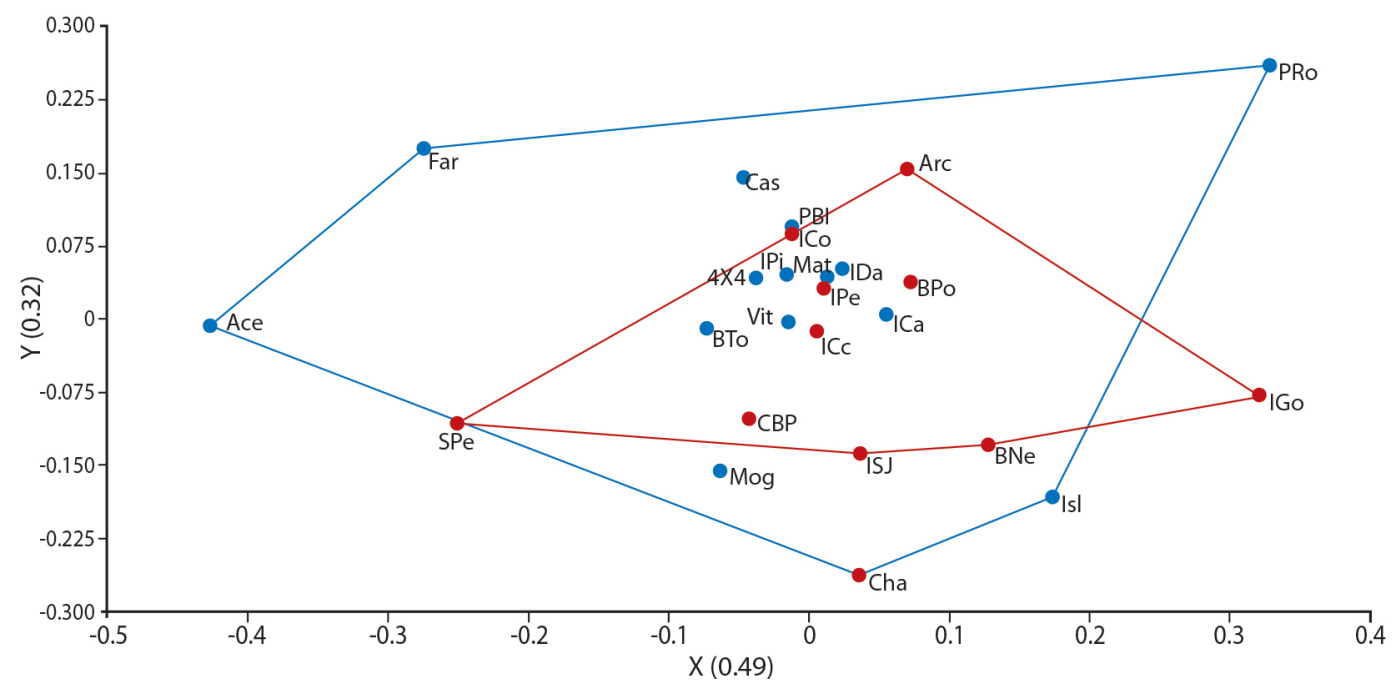

Fig. 3. Non-metric Multidimensional Scaling Analysis for echinoderm family richness and habitat heterogeneity at ACG. Based on Jaccard's distance. Stress level of 0.18. Blue dots represent peninsular sample sites, whereas the red ones represent archipelago sample sites. 
common (Table 3). The most similar sites in the archipelago (Isla Pelada-Bajo Negro) present a widely-distributed families in the ACG (Table 1, Fig. 2).

\section{DISCUSSION}

The 15 echinoderm species previously reported for the ACG (Cortés, 2017), represent only $6 \%$ of the 226 known species for the Pacific of Costa Rica (Alvarado et al., 2017). Two of those, were not collected in our research, the holothuroids Pseudocnus dubiosus and Neothyone gibbosa. The presence of crinoids in the region is still unknown, and possibly they could be found in deeper waters near to the continental slope that is very close to the coast, in the area of the Mesoamerican trench (Cortés, 2017). We found species in ACG that have not been registered for any other coastal locality in Costa Rica, as the sea star Mithrodia bradleyi, and the irregular sea urchin Lovenia cordiformis, that are also present at Isla del Coco (Cortés, 2012). The sea cucumber Trachythyone peruana is a new record for the Costa Rican Pacific waters, while Chiridota aponocrita, Thyone bidentata, and Epitomapta tabogae (until now considered endemic to Panama) are first recorded for the Central American mainland Pacific coasts. We also confirm the presence of the recently described species Holothuria (Mertensiothuria) viridiaurantia, and Ophioderma hendleri for the ACG (Borrero-Pérez \& Vanegas-González, 2019; GranjaFernández, Pineda-Enríquez, Solís-Marín \& Laguarda-Figueras, 2020).

There is a specimen belonging to the family Stichopodidae that does not correspond to any known species in the region (SolísMarín et al., 2009). Externally, the orange bivium is spotted whit irregular (small and large) dark areas of pointed papillae and white little spots on the tegument surface, in the trivium the texture is smooth and the coloration is pale cream, whit dark pelted oral tentacles oriented to the substrate. The skin is thick and soft, the body length is up to $30 \mathrm{~cm}$, and the maximum diameter is near to $10 \mathrm{~cm}$ in the mid-posterior body region. The ossicles of the dermic wall are mainly tables and bars, whit some " $\mathrm{C}$ " and " $\mathrm{S}$ " bodies widely disperse. This specimen had ten pearlfish (Carapidae) inside its cloaca, which got out when their host died. We speculate that when the water $\mathrm{O}_{2}$ concentration of its container dropped to hypoxia, the stressed fish got outside.

Two other morpho-species of the family Holothuriidae, have a combination of tables, buttons, and perforated plaques that do not match whit the ossicles for reported species. One of them has a homogeneous white color whit disperse minute yellow dots over the bivium, as well on the tip of their podia, at trivium. The top of the pelted oral tentacles was yellow too. The skin is rugose, nor thin or thick, and has neither kind of distinguishable ossicle on dermic tissue samples. The total length of this animal was $2 \mathrm{~cm}$ approx. Other holothurid morpho-species have a combination of characters, including light or dark greenbrown tegument surface, whit yellowish pelted oral tentacles and projected podia on the trivium, at bivium surface the skin has a rugose appearance, the length is up to $5 \mathrm{~cm}$ and close to $2 \mathrm{~cm}$ wide, by ossicle comparison we were not able to distinguish between them and other Holothuria spp.

Finally, the discovery of Ophioplocus hancocki in ACG extents the distribution range to this species. Collected during the Allan Hancock expeditions (1933 and 1934) and thought to be endemic for the Galápagos Islands (Ziesenhenne, 1940; Maluf, 1991). Currently, there are three specimens in the Smithsonian's National Museum of Natural History, a holotype, and two vouchers (https://collections.nmnh.si.edu/ search/iz/?q=qn+Ophioplocus+hancocki). In addition to a paratype and seven vouchers at the Museum of Comparative Zoology at Harvard University (https://mczbase.mcz.harvard.edu/SpecimenResults.cfm?taxon_name $\mathrm{id}=446882$ ). So, the specimen collected during the expeditions of the BioMar-ACG Project constitutes the twelfth specimen recorded in scientific collections for this species. 
As found for other groups of marine organisms studied in the BioMar-ACG Project, echinoderms richness has been underestimated (Vargas-Castillo \& Cortés, 2019; Cortés \& Joyce, 2020). When compared to other marine areas of Costa Rica, like the Osa Peninsula and Isla del Coco, the ACG Marine Sector registered a low echinoderm mean diversity (Alvarado et al., 2017). The research efforts carried out by the BioMar-ACG project release an update of 1. 479 marine species, a richness comparable to other highly rich, but more extensive regions of the Eastern Tropical Pacific (Cortés \& Joyce, 2020). That could be explained by the high environmental heterogeneity on the rugged littoral structure and the seasonal upwelling in the region, which increases primary productivity and together may increase the chance to support a higher species richness and densities (Cortés, 2014; Cortés \& Joyce, 2020).

This work demonstrates that the effort and sampling techniques employed determine the knowledge and the interpretations made on the echinoderm diversity of ACG. The taxonomic echinoderm richness of ACG, increased by 20 $\%$. So, we want to highlight the importance of taxonomic baseline studies, as well as the importance to support and publish their results. Which combined with the appropriate tools and technologies, could help us to understand the true diversity of our oceans, the opportunities to legislate them, and the risks of do not. Now, we know that this area presents at least $26 \%$ of the echinoderm species listed for the Costa Rican Pacific (Solís-Marín et al., 2013 Alvarado et al., 2017). And several species that have not been found in any other location in the Central American Pacific. Defining itself as a site of great importance for echinoderm and other marine taxa conservation (Cortés, 2017; Vargas-Castillo \& Cortés, 2019; Cortés \& Joyce, 2020).

Despite some families were exclusively present in one or few sites of the peninsular or the archipelago sectors, the sampled sites were not discretely distributed in the cluster ordination or in the Non-metric Multidimensional Scaling Analysis. Possibly, due to the taxonomic hierarchy used for the construction of the model, as well as the quantity and variability of the environmental factors used. Since many of the substrates were redundant, and the depths between sites were similar, as reflected in the PERMANOVA test. Some research shows that the geographic and temporal scale, as well as the number of variables, and taxonomic resolution are usually decisive in solving the distribution patterns affinities (de Entrambasaguas, 2008; Iken et al., 2010; Alvarado, Guzmán \& Breedy, 2012; Ramírez-Ortiz et al., 2017).

There are echinoderm families with wide distribution, throughout the Eastern Tropical Pacific (Pérez-Ruzafa et al., 2013; Solís-Marín et al., 2013; Lessios \& Baums, 2017). Similar observations of distribution patterns on echinoderms as in other taxonomic groups, have been documented even at larger spatial scales (Glynn \& Ault, 2000; Lessios \& Robertson, 2006; Hellberg, 2009; Duda \& Lessios, 2009; Lessios \& Baums, 2017). For example, when latitude decreases, the richness decreases and the abundance of observed species increase (decrease in alpha diversity and increase in beta diversity), a generalized biogeographic phenomenon in tropical regions, which is usually associated with climatic stability and habitat heterogeneity, that tends to homogenize richness (Iken et al., 2010; González-Gándara et al., 2015; Mutschke, Gerdes \& Ríos, 2017).

Although most of the observed echinoderm families may have planktotrophic larvae, that are able to cross long distances by marine currents and drift (Smith, 1997; Raff \& Byrne, 2006), some species may possibly be restricted by their reproductive strategy and/or its dispersal ability (i.e., O. hancocki, H. lubrica, H. portovallartensis) (Maluf, 1991; Solís-Marín et al., 2013). So, increasing the resolution of taxonomic hierarchies at the species level, as well as the inclusion of functional traits, and genetic analysis could perform our understanding of the echinoderm patterns distribution, habitat use, and dispersal limitation. These data, combined with those from other taxa (corals, mollusks, crustacean, fishes, etc.) adequately interpreted 
and truly used, could lead us to establish criteria in decision-making for the management, conservation, and use of natural resources in the Marine Sector of Área de Conservación Guanacaste, in order to maintain the health of the marine ecosystems, and their resilience to global change and anthropogenic impacts in the area (Janzen, 2000; Cortés \& Joyce, 2020; Janzen \& Hallwachs, 2020). We strongly recommend continuing the research effort on echinoderms in ACG, especially towards new sample sites and deeper waters.

Ethical statement: authors declare that they all agree with this publication and made significant contributions; that there is no conflict of interest of any kind; and that we followed all pertinent ethical and legal procedures and requirements. All financial sources are fully and clearly stated in the acknowledgements section. A signed document has been filed in the journal archives.

\section{ACKNOWLEDGMENTS}

We thank Frank Joyce, Yelba Vega, Gilberth Ampié, Minor Lara, Anibal Lara, Carolina Sheridan-Rodríguez, Cristian Mora-Barboza, and Génesis Coto for their support during sampling. We are thankful to Juan Ignacio AbarcaOdio for his advice on statistical analysis. We are grateful to Rebeca Granja-Fernández and Francisco Solís-Marín for their comments on our results. We thank the park rangers of the Isla San José station at Murciélago Islands for their support in the expeditions. This study was possible due to the support of the Center for Research in Marine Sciences and Limnology (CIMAR), Museo de Zoología (MZ-UCR), and Escuela de Biología of the Universidad de Costa Rica. The BioMar-ACG project was funded by the Guanacaste Dry Forest Conservation Fund (GDFCF). Sampling permits were granted by the National System of Conservation Areas (SINAC). We are very thankful to the Iberoamerican Network of Echinoderms and the organizing team of the 4th Latin American Congress on Echinoderms. Finally, we thank three anonymous scientific revisors of our manuscript and to the scientific editors of the supplement.

\section{RESUMEN}

\section{Equinodermos del Área de Conservación Guanacaste,} Pacífico Norte de Costa Rica

Introducción: El estudio de la diversidad marina del Pacífico Norte de Costa Rica inició con expediciones extranjeras aisladas en la década de 1930, y fue desarrollado sistemáticamente a mediados de la década de 1990 por el Centro de Investigaciones en Ciencias del Mar y Limnología de la Universidad de Costa Rica, como consecuencia ahora se reporta un total de 1479 especies en esta región. Objetivo: Presentar una actualización de la riqueza de equinodermos del Área de Conservación Guanacaste. Métodos: Realizamos muestreos exhaustivos en 25 localidades y estimamos la similitud entre sitios con base en la riqueaza de familias y la heterogeneidad ambiental. Resultados: Encontramos 61 taxa, que representan el 26\% de las especies reportadas para la costa pacífica del país. De estas, 43 especies son nuevos registros para el Área de Conservación Guanacaste y siete para las costas de Costa Rica y el Pacífico centroamericano. Tres morfoespecies no coinciden con las descripciones disponibles para las especies del Pacífico Tropical Oriental. Por último, hallamos un ejemplar del holoturoideo Epitomapta tabogae y otro del ofiuroideo Ophioplocus hancocki, considerados endémicos para Panamá y las Islas Galápagos respectivamente. La proximidad entre los sitios muestreados y la redundancia de ciertas familias pueden explicar por qué no se encontraron diferencias entre las localidades. Conclusiones: La riqueza de equinodermos de esta área de conservación es al menos $20 \%$ mayor que la reportada anteriormente, alcanzando niveles similares a los de otros sitios de alta diversidad del Pacífico Tropical Oriental.

Palabras clave: Islas Murciélago; Santa Elena; afloramiento costero; colecciones científicas; taxonomía; Echinodermata

\section{REFERENCES}

Alfaro, E.J. \& Cortés, J. (2012). Atmospheric forcing of cold subsurface water events in Bahía Culebra, Costa Rica. Revista de Biología Tropical, 60(Suppl. 2), 173-186.

Alvarado, J.J., Guzmán. H. \& Breedy, O. (2012). Distribution and diversity of echinoderms (Asteroidea, Echinoidea, Holothuroidea) in the islands of the Gulf of Chiriqui, Panama. Revista de Biología Marina y Oceanografia, 47(1), 13-22. 
Alvarado, J.J., Chacón-Monge, J.L., Solís-Marín, F.A., Pineda-Enríquez, T., Caballero-Ochoa, A.A., Solano Rivera, S., \& Romero Chaves, R. (2017). Equinodermos del Museo de Zoología de la Universidad de Costa Rica. Revista de Biología Tropical, 65(Supl. 1), 272-287.

Alvarado, J.J., Cortés, J., Esquivel, M.F. \& Salas, E. (2012). Costa Rica's Marine Protected Areas: status and perspectives. Revista de Biología Tropical, 60 (1), 129-142.

Anderson, M. (2017). Permutational Multivariate Analysis of Variance (PERMANOVA). In: Balakrishnan, N., Colton, T., Everitt, B., Piegorsch, W., Ruggeri, F. \& Teugels, J. (Eds.), Wiley StatsRef: Statistics Reference Online, 1-15.

Borrero-Pérez, G.H. \& Vanegas-González, M.J. (2019). Holothuria (Mertensiothuria) viridiaurantia sp. nov. (Holothuriida, Holothuriidae), a new sea cucumber from the Eastern Pacific Ocean revealed by morphology and DNA barcoding. ZooKeys, 893, 1-19.

Cambronero-Solano, S., Benavides, R., Solís-Marín. F.A. \& Alvarado, J.J. (2019). New reports of echinoderms on the Caribbean continental slope of Central America. Zoosymposia, 15, 5-12.

Cortés, J. (2012). Marine biodiversity of an Eastern Tropical Pacific oceanic island, Isla del Coco, Costa Rica. Revista de Biología Tropical, 60(Suppl. 3), 131-185.

Cortés, J. (2016). The Pacific coastal and marine ecosystems. In M. Kappelle (Ed.), Costa Rican Ecosystems (pp. 97-138). Chicago and London: University of Chicago Press.

Cortés, J. (2017). Marine biodiversity baseline for Área de Conservación Guanacaste, Costa Rica: published records. ZooKeys, 652, 129-179.

Cortés, J. \& Joyce, F. (2020). BioMar-ACG: A successful partnership to inventory and promulgate marine biodiversity. Biotropica, 52, 1104-1107. DOI: 10.1111/ btp.12841.

Cortés, J., Samper-Villarreal, J. \& Bernecker, A. (2014). Seasonal phenology of Sargassum liebmannii J. Agardh (Fucales, Heterokontophyta) in an upwelling area of the Eastern Tropical Pacific. Aquatic Botany, $119,105-110$.

Costello, M.J., Michener, W. K., Gahegan, M., Zhang, Z.Q. \& Bourne, P.E. (2013). Biodiversity data should be published, cited, and peer reviewed. Trends in Ecology \& Evolution, 28, 454-461.

de Entrambasaguas, M.L. (2008). Estudio faunístico y ecológico de los equinodermos del archipiélago de Cabo Verde (Doctoral dissertation). Universidad de Murcia, Spain.

Duda, T.F. \& Lessios, H.A. (2009). Connectivity of populations within and between major biogeographic regions of the tropical Pacific in Conus ebraeus, a widespread marine gastropod. Coral Reefs, 28, 651-659.

González-Gándara, C., Solís-Marín, F.A. de la CruzFrancisco V., Granados-Barba, A., Salas-Pérez, J.J., Argüelles-Jiménez J. \& Escárcega-Quiroga, P. A. (2015). Riqueza y distribución de equinodermos en los arrecifes del norte de Veracruz, México. Revista de Biología Tropical, 63(2), 183-193.

Granja-Fernández, R., Herrero-Pérezrul, M., López-Pérez, R., Hernández, L., Rodríguez-Zaragoza, F., Wallace Jones, R. \& Pineda-López, R. (2014). Ophiuroidea (Echinodermata) from coral reefs in the Mexican Pacific. ZooKeys, 406, 101-145.

Granja-Fernández, R., Pineda-Enríquez, T., Solís-Marín, F.A. \& Laguarda-Figueras, A. (2020). Ophioderma hendleri sp. nov. (Echinodermata: Ophiuroidea: Ophiodermatidae) and its congeners from the Eastern Pacific. European Journal of Taxonomy 729: 11-41.

Glynn, P.W. \& Ault, J.S. (2000). A biogeographic analysis and review of the far eastern Pacific coral reef region. Coral Reefs, 19, 1-23.

Hebert, P.D.N., Cywinska, A., Ball, S. L. \& deWaard, J. R. (2003). Biological identifications through DNA barcodes. Proceedings of the Royal Society of London. Series B: Biological Sciences, 270, 313-321.

Hellberg, M.E. (2009). Gene flow and isolation among populations of marine animals. Annual Review of Ecology, Evolution, and Systematics, 40, 291-310.

Iken, K., Konar, B., Benedetti-Cecchi, L., Cruz-Motta, J.J., Knowlton, A., Pohle, G., . . . Silva, A. (2010). Largescale spatial distribution patterns of echinoderms in nearshore rocky habitats. PLOS ONE, 5(11), e13845.

Janzen, D.H. (2000). Costa Rica's Area de Conservación Guanacaste: a long march to survival through nondamaging biodevelopment. Biodiversity, 1(2):7-20.

Janzen, D.H. \& Hallwachs, W. (2016). Biodiversity conservation history and future in Costa Rica: The case of area de Conservación Guanacaste (ACG). Chapter 10. In C. R. Ecosystems \& M. Kappelle (Eds.), Biodiversity conservation history and future in Costa Rica (pp. 290-341). Chicago, IL: University of Chicago Press.

Janzen, D.H. \& Hallwachs, W. (2019). How a tropical country can DNA barcode itself. iBOL Barcode Bulletin, 9(1), 1-6.

Janzen, D.H. \& Hallwachs, W. (2020). Área de Conservación Guanacaste, northwestern Costa Rica: Converting a tropical national park to conservation via biodevelopment. Biotropica, 52, 1017-1029.

Lessios, H.A. (2005). Echinoids of the Pacific waters of Panama: Status of knowledge and new records. Revista de Biología Tropical, 53(3), 147-170. 
Lessios, H.A. \& Baums, I.B. (2017). Gene flow in coral reef organisms of the Tropical Eastern Pacific. In Glynn, P., Mazello, D. \& Enochs, I. (Eds.), Coral Reefs of the Eastern Tropical Pacific: Persistence and Loss in a Dynamic Environment (pp. 477-499). Netherlands: Springer-Verlag.

Lessios, H.A. \& Robertson, D.R. (2006). Crossing the impassable: genetic connections in 20 reef fishes across the eastern Pacific barrier. Proceedings of the Royal Society B: Biological Sciences, 273, 2201-2208.

Lizano, O. G. \& Alfaro, E. J. (2014). Características de la dinámica atmosférica y oceánica en algunas regiones del Área de Conservación Guanacaste (ACG), Costa Rica. Revista de Biología Tropical, 62(Supl. 4), 17-31.

Maluf, L.Y. (1991). Echinoderm fauna of the Galápagos Islands. In M. James (Ed.), Galápagos Marine Invertebrates (pp. 345-367). New York, USA: Springer Science, Business Media.

MCZbase. (2020). The Database of the Zoological Collections Museum of Comparative Zoology - Harvard University. Available from https://mczbase.mcz. harvard.edu/SpecimenResults.cfm?taxon name id $=446882$. Accessed 2020-07-13.

Mutschke, E., Gerdes, D. \& Ríos, C. (2017). Distribution and abundance patterns of echinoderms in the fjord and channel complex from a subantarctic north Patagonian Ice field, Magellan region. Revista de Biología Tropical, 65(1), 60-72.

Pérez-Ruzafa, A., Alvarado, J.J., Solís-Marín, F.A., Hernández, J.C., Morata, A., Marcos, C., . . . Williams, S.M. (2013). Latin America echinoderm biodiversity and biogeography: Patterns and affinities. In J.J. Alvarado \& F.A. Solís-Marín (Eds.), Echinoderm Research and Diversity in Latin America (pp. 511 -542). Berlin: Springer Heidelberg.

Raff, R. \& Byrne, M. (2006). The active evolutionary lives of echinoderm larvae. Heredity, 97, 244-252.

Ramírez-Ortiz, G., Calderón-Aguilera, L.E., Reyes-Boni1la, H., Ayala-Bocos, A., Hernández, L., Rivera-Melo, F.F., . . . Dominici-Arosamena, A. (2017). Functional diversity of fish and invertebrates in coral and rocky reefs of the Eastern Tropical Pacific. Marine Ecology, $38, \mathrm{e} 12447$.

SINAC (Sistema Nacional de Áreas de Conservación). 2013. Plan de Manejo Área de Conservación Guanacaste 2014-2024. ACG. Guanacaste. 149 p.

Smith, A. (1997). Echinoderm larvae and phylogeny. Annual Review of Ecology, Evolution, and Systematics, 2, 219-241.

Smithsonian Institution. (2020). Smithsonian National Museum of Natural History. Available from https://collections.nmnh.si.edu/search/ $\mathrm{iz} / ? \mathrm{q}=\mathrm{qn}+$ Ophioplocus + hancocki. 2020-07-13.

Accessed

Solís-Marín, F.A., Alvarado, J.J., Abreu-Pérez, M., Aguilera, O., Alió, J., Bacallado-Aránega, J.J., . . . Williams, S.M. (2013). Appendix. In J.J. Alvarado \& F.A. Solís-Marín (Eds.), Echinoderm Research and Diversity in Latin America (pp. 543-654). Berlin: Springer Heidelberg.

Solís-Marín, F.A., Arriaga-Ochoa, J.A., Laguarda-Figueras, A., Frontana-Uribe, S.C. \& Durán-González, A. (2009). Holothuroideos (Echinodermata: Holothuroidea) del Golfo de California, México. México: Comisión Nacional para el Conocimiento y Uso de la Biodiversidad e Instituto de Ciencias del Mar y Limnología, UNAM.

Solís-Marín, F.A., Laguarda-Figueras, A., Estrada-Rodríguez, P., Honey-Escandón, M., Cao-Romero, C. \& Durán-Gonzáles, A. (2014). Los asteroideos (Echinodermata: Asteroidea) del Golfo de California, México. México: UNAM), Instituto de Ciencias del Mar y Limnología, Secretaría de Medio Ambiente y Recursos Naturales e Instituto Nacional de Ecología y Cambio Climático.

Toral-Granda, V. (2008). Population status, fisheries and trade of sea cucumbers in Latin America and the Caribbean In: Toral-Granda, V., Lovatelli, A. \& Vasconcellos, M. (Eds.). Sea Cucumbers. A Global Review of Fisheries and Trade (pp. 213-229). Roma: FAO Fisheries and Aquaculture Technical Paper No. 516.

Vargas-Castillo, R. \& Cortés, J. (2019). New records of marine decapods and stomatopods in Área de Conservación Guanacaste (ACG): four years of marine biodiversity inventorying. Marine Biodiversity Records, 12(1), 1-8.

Villalobos-Rojas, F., Herrera-Correa, J. Garita-Alvarado, C., Clarke, T. \& Beita-Jiménez, A. (2014). Actividades pesqueras dependientes de la ictiofauna en el Pacífico Norte de Costa Rica. Revista de Biología Tropical, 62 (Supl. 4), 119-138.

World Heritage Committee. (2013). Thirty seventh session. WHC-13/37.COM/8E: Adoption of retrospective Statements of Outstanding Universal Value, UNESCO. $302 \mathrm{p}$.

Worm, B., Barbier, E.B., Beaumont, N., Duffy, J.E., Folke, C., Halpern, B.S., Jackson, J.B.C., . . . Watson, R. (2006). Impacts of biodiversity loss on ocean ecosystem services. Science 314: 787-790.

WoRMS Editorial Board (2020). World Register of Marine Species. Available from http://www.marinespecies. org at VLIZ. Accessed 2020-07-13.

Ziesenhenne, F.C. (1940). New ophiurans of the Allan Hancock Pacific Expeditions. Allan Hancock Pacific Expeditions, 8(2), 9-59. 